\title{
The Boundaries of EU Copyright Law: Cheese, Jeans and a Military Report in the Court of Justice*
}

Nuno Sousa e Silva $a^{* *}$

\begin{abstract}
Copyright is a centrepiece in the ongoing construction of the digital single market. Evidently, copyright only applies to works. Thus, the definition of its scope lies in knowing what a work is. Although that was not envisioned nor intended by the lawmaker, the Court of Justice has adopted a European notion of work in its controversial decision C-5/08, Infopaq, conflating it with the one of originality. Such an approach has been confirmed and expanded by subsequent case law. The Court has already fleshed out the main criterion for a creation to enjoy copyright - it must be original in the sense of being the author's own creation - and seems to reject any additional criteria. However, the boundaries of the European notion of work are still unknown. Some recent preliminary ruling requests will allow some clarification. One asks about the possibility of copyright protection for the taste of a specific cheese (C-310/17, Levola Hengelo). Another one deals with the protection of a fashion design for jeans (C-683/17, Cofemel) and yet another concerns a military report (C-469/17, Funke Medien). After describing the evolution of the law on the EU notion of copyright, this article frames and critically analyses the questions surrounding these cases, proposes answers thereto and makes a prediction of the outcome, i.e. the Court's decision, in each of them.
\end{abstract}

KEYWORDS: Copyright; work; EU law; Court of Justice; harmonisation

\footnotetext{
* Date of Reception: 30 January 2019. Date of Acceptance: 21 February 2019.

** Assistant Lecturer at the Porto Faculty of Law, Universidade Católica Portuguesa. nsousaesilva@gmail.com.
} 


\section{Introduction}

What is art and does it matter for copyright? What do we know so far about the European autonomous concept of (copyright) work? Will three cases involving cheese, jeans and a military report further our understanding? Are there limits to it? These are the questions I wish to explore in this article.

Copyright is one of the most important aspects of the ongoing process of building a digital single market. ${ }^{1}$ Copyright is a bundle of rights giving the holder (not necessarily the author) of a work the power to control its use and exploitation. Understanding if a certain creation qualifies as a work is the starting point of any copyright litigation. In fact, the concept of copyright work is at the heart of the whole discipline. That determination involves two steps: first, determining if a certain creation is copyright subject matter (in the words of the Berne Convention, a "production in the literary, scientific and artistic domain"), and, second, ascertaining if the requirements for protection, namely originality, are met.

Traditionally the notion of (a copyright protected) work was understood very differently in copyright (common law) and droit d'auteur systems. ${ }^{2}$ Whereas the former required fixation, had a closed list of categories of creations that could qualify as works and presented a lower threshold in terms of originality, the latter did not require fixation, used an open list of creations but required a higher degree of originality in order for a creation to qualify for copyright protection. ${ }^{3}$ Although significant, these differences only played a role at the margins. It was beyond doubt that books, movies, sculptures and paintings in general qualified as works under both systems. ${ }^{4}$ It was only when dealing with objects of very low creative content such as catalogues, timetables or lists of sports results that outcomes diverged. Legal systems like the UK or Ireland would attribute copyright

\footnotetext{
${ }^{1}$ European Commission, Communication from the Commission to the European Parliament, the Council, the European Economic and Social Committee and the Committee of the Regions "A Digital Single Market Strategy For Europe” (COM/2015/0192 final) 6 May 2015. https://eur-lex.europa.eu/ legal-content/EN/TXT/?qid=1447773803386\&uri=CELEX:52015DC0192.

${ }^{2}$ For an in-depth analysis of the differences see Alain Strowel, Droit d'Auteur et Copyright, Divergences et Convergences: Étude de Droit Comparé (Bruxelles: E. Bruylant, 1994).

${ }^{3}$ See the comparative overview in Daniel Gervais, "Feist goes global: A comparative analysis of the notion of originality in copyright law", Journal of the Copyright Society of the U.S.A. 49 (2002): 949-981. See also Ramón Casas Vallés, "The requirement of originality", in Research Handbook on the Future of EU Copyright, ed. Derclaye, Estelle (Cheltenham: Edward Elgar, 2009), 102-132.

${ }^{4}$ Lionel Bently, Brad Sherman, Dev Gangjee, and Phillip Johnson, Intellectual Property Law (Oxford: Oxford University Press, 2018), 102.
} 
to this sort of creations, contrary to what German or French courts would decide. $^{5}$

The intervention of the EU in the field of copyright has caused major changes. Due to the national sensitivities, the harmonisation of the notion of work has been not so much a work of the lawmaker. The real actor, revolutionary, and some would say usurper, has been the Court of Justice. ${ }^{6}$

Beginning in 2009 with decision C-5/08, Infopaq, and over the course of almost a decade, the Court of Justice has elected the main criterion for a creation to enjoy copyright - it must be original in the sense of being the author's own creation -, further explained it - referring to a content of creativity resulting from free voluntary choices - and seems to reject any additional criteria. However, the boundaries of the European notion of work are still unknown, and doubts linger concerning both subject matter and other requirements for protection.?

It is expected that some recent preliminary ruling requests will allow further clarification. One, already decided, deals with the possibility of copyright protection for the taste of a cheese (C-310/17, Levola Hengelo, EU:C:2018:899). Another one, still pending, asks about the protection of a fashion design for jeans (C-683/17, Cofemel) and yet another, pending as well, concerns a military report (C-469/17, Funke Medien).

After describing the evolution of the law on the EU notion of copyright, this article frames and critically analyses the questions surrounding these cases, proposes answers thereto and, finally, for those that are still pending, makes a prediction of the respective outcome.

\footnotetext{
${ }^{5}$ Thomas Margoni, "The harmonisation of EU copyright law: The originality standard", in Global Governance of Intellectual Property in the $21^{\text {st }}$ Century: Reflecting Policy through Change, ed. Perry, Mark (Cham: Springer, 2016), 92-94.

${ }^{6}$ Along these lines, criticising the resulting fragmentation of the Court's intervention, cf. Florian Jotzo, "Der EuGH als Interimsnormgeber im digitalen Urheberrecht", Zeitschrift für Geistiges Eigentum 9(4) (2017): 447-470. For an empirical analysis of 40 decisions see Marcella Favale, Martin Kretschmer and Paul C. Torremans, "Is there a EU copyright jurisprudence? - An empirical analysis of the workings of the European Court of Justice", The Modern Law Review (2016) 31-75, concluding (at 70) that "the empirical analysis seems to suggest that while the Court's jurisprudence is in better shape than critiques suggest, much could be done to improve its legitimacy". ${ }^{7}$ Discussing the harmonisation of copyright subject matter see the contribution of Tanya Aplin, "Subject matter", in Research Handbook on the Future of EU Copyright, ed. Derclaye, Estelle (Cheltenham: Edward Elgar, 2009), 49-76.
} 


\section{The legislative beginnings}

When the EU began to legislate in the field of copyright, by means of a Directive on computer programs (Council Directive 91/250/EEC of 14 May 1991, now codified in Directive 2009/24/EC of the European Parliament and of the Council of 23 April 2009, known as the "Software Directive"), the need was felt to find a compromise between the very demanding German case law and the more lenient one in the UK.

Bearing this in mind, the solution was to state that: "A computer program shall be protected if it is original in the sense that it is the author's own intellectual creation. No other criteria shall be applied to determine its eligibility for protection" (Article 1(3) of the Software Directive). This originality criterion was to be seen as a middle ground between the two approaches. ${ }^{8}$

The second instance where this approach was followed was photographs. There are significant differences in the legal treatment of photography in the EU. ${ }^{9}$ Some Member States, like Spain and Germany, have a neighbouring right for simple photos (which do not qualify for copyright protection), while others do not. When it came to harmonising the duration of copyright in the EU, it was felt that there should be a common criterion to determine the copyright eligibility of photographs. Thus when enacting Council Directive 93/98/EEC of 29 October 1993 harmonising the term of protection of copyright and certain related rights (now replaced by Directive 2006/116/EC of the European Parliament and of the Council of 12 December 2006, known as the "Duration Directive"), once again the lawmaker chose originality "in the sense that it is the author's own intellectual creation" (Article 6 of the Duration Directive).

A similar discussion arose when Directive 96/9/EC of the European Parliament and of the Council of 11 March 1996 on the legal protection of databases was being drafted. Factual works, such as compilations, lists, and catalogues were easily protected by copyright under English law. Yet, in continental Europe these were subject to unfair competition laws and/ or neighbouring rights and seen as lacking the necessary degree of originality demanded by copyright law. The solution was to find a similar compromise: originality "in the sense that it is the author's own intellectual

\footnotetext{
${ }^{8}$ Eleonora Rosati, Originality in EU Copyright: Full Harmonization through Case Law (Cheltenham, UK: Edward Elgar, 2013), 65.

${ }^{9}$ For a comparative overview see Ysolde Gendreau (ed.), Copyright and Photographs: An International Survey (London: Kluwer Law International, 1999).
} 
creation" would be the single criterion to ascertain whether a database was eligible for copyright protection. ${ }^{10}$

It was therefore understood that, except for these three categories of works - software, databases, and photographs - the originality standard was not harmonised. ${ }^{11}$ However, in July 2009, the Court of Justice changed that perception. ${ }^{12}$

\section{The Infopaq revolution}

In the Infopaq case the Court of Justice was asked to rule on whether clipping (i.e. the use of small snippets of text) of news articles was a reproduction in the sense of Article 2 of the Infosoc Directive (Directive 2001/29/ EC of the European Parliament and of the Council of 22 May 2001 on the harmonisation of certain aspects of copyright and related rights in the information society).

The Court associated the notion of reproduction, which had been harmonised horizontally (i.e. for all copyright works) by the Infosoc Directive, to the notion of originality, by saying "copyright within the meaning of Article 2(a) of Directive 2001/29 is liable to apply only in relation to a subject-matter which is original in the sense that it is its author's own intellectual creation". ${ }^{13}$

Discussing the creation at hand (newspaper articles), it elaborated further: "Regarding the elements of such works covered by the protection, it should be observed that they consist of words which, considered in isolation, are not as such an intellectual creation of the author who employs them. It is only through the choice, sequence and combination of those words that the author may express his creativity in an original manner and achieve a result which is an intellectual creation". ${ }^{14}$

Thus, the Court concluded: "In the light of those considerations, the reproduction of an extract of a protected work which, like those at issue

\footnotetext{
${ }^{10}$ Thomas Margoni, “The harmonisation”, 94.

${ }^{11}$ It was even debated the extent to which these three directives established similar yardsticks due to minor textual differences (see Rosati, Originality, 67-68).

${ }^{12}$ Although the Court's intervention was mostly unexpected some authors had predicted it (cf. Herman Cohen Jehoram, "Cumulation of protection in the EC design proposals", European Intellectual Property Review 16 (1994): 519-520).

${ }^{13}$ Judgment of 16 July 2009, Infopaq International A/S v. Danske Dagblades Forening, C-5/08, EU:C:2009:465, paragraph 37.

${ }^{14}$ Judgment of 16 July 2009, Infopaq International A/S v. Danske Dagblades Forening, C-5/08, EU:C:2009:465, paragraph 45.
} 
in the main proceedings, comprises 11 consecutive words thereof, is such as to constitute reproduction in part within the meaning of Article 2 of Directive 2001/29, if that extract contains an element of the work which, as such, expresses the author's own intellectual creation; it is for the national court to make this determination". ${ }^{15}$

With this decision the Court of Justice, through the coupling of reproduction and originality, used a horizontally harmonised concept (reproduction) to arguably harmonise another (work). ${ }^{16}$ In the Court's view, since knowing if a partial reproduction occurs hinges on whether the object of reproduction is capable in itself of being protected by copyright, the harmonisation of the right of reproduction for the whole of copyright meant it must also adjudicate on the criteria for the protection of any creation by copyright. In that sense the notion of work becomes harmonised to the extent that the reproduction right already is, since from this perspective they are inseparable.

Although being a major change, the real practical impact of this view could be doubted. In the words of Estelle Derclaye, "This is quite revolutionary and can be shocking (if not choking) for most British practitioners and perhaps also most British academics. But does it change much in practice? The vast majority of musical and dramatic works will be creative, so for these, Infopaq does not change much". ${ }^{17}$

Nonetheless, the Court chose a criterion of creativity not as demanding as the German nor too lax as the British to determine whether a creation is eligible for copyright protection. ${ }^{18}$ This should mean changes for national laws, even if only marginally.

The confirmation of this approach-deemed of "creeping harmonization"19 - did not take long.

\footnotetext{
${ }^{15}$ Judgment of 16 July 2009, Infopaq International A/S v. Danske Dagblades Forening, C-5/08, EU:C:2009:465, paragraph 48.

${ }^{16}$ Bently, Sherman, Gangjee, and Johnson, Intellectual Property, 98.

${ }^{17}$ Estelle Derclaye, "Infopaq International A/S v. Danske Dagblades Forening (C-5/08): Wonderful or worrisome? The impact of the ECJ ruling in Infopaq on UK copyright law", European Intellectual Property Review 32 (2010): 249.

${ }^{18}$ Derclaye, "Infopaq International", 249: "artistic works now clearly need to be creative in order to be protected".

${ }^{19}$ Gernot Schulze, "Schleichende Harmonisierung des urheberrechtlichen Werkbegriffs? Anmerkung zu EuGH "Infopaq/DDF”, Gewerblicher Rechtsschutz und Urheberrecht (2009): 10191022. Schulze was very critical of the approach and at the time rejected the reading that attributed wider effects to the decision.
} 


\section{The confirmation}

In 2011, in the Bezpečnostni softwarová associasse (BSA) decision, ${ }^{20}$ the Court of Justice had to consider if Graphic User Interfaces (GUI) could be protected by copyright. Having rejected that these could be qualified as software, ${ }^{21}$ the Court nonetheless accepted that GUI could be protected under "ordinary"/general copyright, provided these were original. ${ }^{22}$ And the definition of originality for that purpose as "its author's own intellectual creation" was done citing Infopaq. ${ }^{23}$

Proceeding with the analysis the CJEU spelled out the "merger doctrine" according to which "where the expression of (...) components is dictated by their technical function, the criterion of originality is not met, since the different methods of implementing an idea are so limited that the idea and the expression become indissociable". ${ }^{4}$ Thus, "In such a situation, the components of a graphic user interface do not permit the author to express his creativity in an original manner and achieve a result which is an intellectual creation of that author". ${ }^{25}$

Trailing on this approach, decisions such as Karen Murphy (discussing inter alia whether sports events, namely football matches, could be protected by copyright and deciding in the negative), ${ }^{26}$ Football Dataco (dealing with the copyright eligibility of football league fixtures and rejecting the relevance of the intellectual effort and skill of creating that data), ${ }^{27}$ SAS Institute (analysing the possibility of copyright protection of the functionality of a computer program, its programming language and

\footnotetext{
${ }^{20}$ Judgment of 22 December 2010, BSA v. Ministerstvo kultury, C-393/09, EU:C:2010:816.

${ }^{21}$ Judgment of 22 December 2010, BSA v. Ministerstvo kultury, C-393/09, EU:C:2010:816, paragraph 42: "...that interface does not constitute a form of expression of a computer program within the meaning of Article 1(2) of Directive 91/250 and that, consequently, it cannot be protected specifically by copyright in computer programs by virtue of that directive".

${ }^{22}$ Judgment of 22 December 2010, BSA v. Ministerstvo kultury, C-393/09, EU:C:2010:816, paragraphs 44 and 46 .

${ }^{23}$ Judgment of 22 December 2010, BSA v. Ministerstvo kultury, C-393/09, EU:C:2010:816, paragraph 45 .

${ }^{24}$ Judgment of 22 December 2010, BSA v. Ministerstvo kultury, C-393/09, EU:C:2010:816, paragraph 49 .

${ }^{25}$ Judgment of 22 December 2010, BSA v. Ministerstvo kultury, C-393/09, EU:C:2010:816, paragraph 50 .

${ }^{26}$ Judgment of 4 October 2011, Karen Murphy v. Media Protection Services Ltd., C-403/08 and C-429/08, EU:C:2011:631.

${ }^{27}$ Judgment of 1 March 2012, Football Dataco Ltd. and Others v. Yahoo! UK Ltd and Others,

C-604/10, EU:C:2012:115.
} 
the format of data files), ${ }^{28}$ and Nintendo (debating the copyright eligibility of videogames $)^{29}$ have maintained the criterion and further developed its contours. $^{30}$

\section{How far did it go?}

Amidst these developments, the Court of Justice had to deal with a preliminary ruling request concerning the compatibility of certain provisions of Italian copyright law and EU law.

Up until 2001, Italian law was very restrictive on the eligibility of works of applied arts (design pieces such as furniture, lighting, clothes, tools, utensils or jewellery) for copyright protection. ${ }^{31}$ However, due to the transposition of the Design Directive (Directive 98/71/EC of the European Parliament and of the Council of 13 October 1998 on the legal protection of designs), Italian law was altered with the removal of the main impediment to copyright protection of applied arts. ${ }^{32}$

In the course of litigation between two lamp producers, the compatibility of these changes and the transitory provision established therewith with the Design Directive was questioned. This led to the Flos ruling. ${ }^{33}$

Even though this was not essential to answer the questions posed, the Court stated that "it is conceivable that copyright protection for works which may be unregistered designs could arise under other directives concerning copyright, in particular Directive 2001/29, if the conditions for that directive's application are met, a matter which falls to be determined by the national court". ${ }^{34}$

\footnotetext{
${ }^{28}$ Judgment of 2 May 2012, SAS Institute Inc. v. World Programming Ltd., C-406/10, EU:C:2012:259.

${ }^{29}$ Judgment of 23 January 2014, Nintendo Co. Ltd and Others v. PC Box Srl and 9Net Srl, C-355/12, EU:C:2014:25.

${ }^{30}$ Eleonora Rosati, Originality, 187; Matthias Leistner, "Copyright at the interface between EU law and national law: Definition of 'work' and 'right of communication to the public", Journal of Intellectual Property Law \& Practice (2015): 626.

${ }^{31}$ On the interactions of copyright and design see the various contributions to Estelle Derclaye (ed.), The Copyright/Design Interface: Past, Present and Future (Cambridge: Cambridge University Press, 2018).

${ }^{32}$ The evolution of Italian law in this regard is explained further in Estelle Derclaye, "The copyright/design interface in Italy", in The Copyright/Design Interface, ed. Derclaye, 269-296.

${ }^{33}$ Judgment of 27 January 2011, Flos SpA v. Semeraro Casa and Famiglia SpA, C-168/09, EU:C:2011:29.

${ }^{34}$ Judgment of 27 January 2011, Flos SpA v. Semeraro Casa and Famiglia SpA, C-168/09, EU:C:2011:29, paragraph 34.
} 
The meaning of this obiter dicta was (and still is) far from clear. Some commentators claimed it meant that the harmonisation of the notion of work also occurred in the field of designs ${ }^{35}$ However, the Bundesgerichtshof was not at all convinced. In the influential Geburtstagszug decision, the designer of a toy train with candles and numbers invoked a provision of German copyright law to claim additional remuneration due to the success of her design. ${ }^{36}$ The granting of that request hinged, first and foremost, on knowing whether the design in question was eligible for copyright protection.

In this decision the German Supreme Court changed its previous caselaw (which applied a more demanding standard for works of applied art than for copyright in general) but rejected the view that it was EU law that required such a change. ${ }^{37}$ In fact, it adopted a criterion that seems to run counter European case-law. According to the decision of the BGH, works of applied art, besides being original, must be regarded as artistic by the interested circles in order to be protected by copyright law. ${ }^{38}$

On the contrary, around the same time, in a similar case involving the copyright eligibility of fire stoves, the Dutch Supreme Court (Hoge Raad) held that Flos and Infopaq meant that no additional criteria could apply to consider them original. According to that decision the applicable standard (including in the field of design and the applied arts) was Infopaq's. ${ }^{39}$

These conflicting interpretations are at the heart of the preliminary ruling request in Cofemel discussed below (9.).

\footnotetext{
${ }^{35}$ See in detail Lionel Bently, “The return of industrial copyright?", European Intellectual Property Review 34 (2012): 654-672. Advocate-General Jääskinen, in his Opinion delivered on 29 March 2012 on Case C-5/11, Titus Döner, EU:C:2012:195, paragraph 31 seems to agree. Leistner, "Copyright", 627 highlights the intensity of this debate in German literature.

${ }^{36}$ This is possible according to $\$ 32$ and 32a of the Urheberrechtsgesetz (German Copyright Act). Whenever an author has licenced his copyright for an amount that turns out to be disproportionately low considering the economic success of the work's exploitation (s)he might be entitled to additional remuneration.

${ }^{37}$ I ZR 143/12 Geburtstagszug [rn 31], decision of 13 November 2013. For context and analysis see Ansgar Ohly, "The case for partial cumulation in Germany", in The Copyright/Design Interface, ed. Derclaye, 158-163.

${ }^{38}$ I ZR 143/12 Geburtstagszug [rn 26].

${ }^{39}$ Decision of 25 October 2013, available at http://uitspraken.rechtspraak.nl/inziendocumen t?id=ECLI:NL:PHR:2013:60. As Antoon Quaedvlieg, "The dopyright/design interface in the Netherlands", in The Copyright/Design Interface, ed. Estelle Derclaye, 50-51 mentions, the Court might have assumed too much and should have put the question to the CJEU instead.
} 


\section{What do we know so far?}

Perusing the so far mentioned case law it becomes apparent that the European concept of originality requires free choices capable of expressing the personality of a certain person (that being the author). In that vein, the Court stated in Painer, a case concerning i.e. the copyright eligibility of photograph: $:^{40}$ "an intellectual creation is an author's own if it reflects the author's personality. (...) That is the case if the author was able to express his creative abilities in the production of the work by making free and creative choices". Likewise, it was held in Murphy that: ${ }^{41}$ "sporting events cannot be regarded as intellectual creations classifiable as works within the meaning of the Copyright Directive. That applies in particular to football matches, which are subject to rules of the game, leaving no room for creative freedom for the purposes of copyright". ${ }^{42}$

According to the Court, originality requires a minimum degree of freedom in order for the creator to exercise his discretion, making creative choices that reflect a personality. This was confirmed in SAS Institute: ${ }^{43}$ "It is only through the choice, sequence and combination of those words, figures or mathematical concepts that the author may express his creativity in an original manner and achieve a result, namely the user manual for the computer program, which is an intellectual creation".

As a corollary of the idea of "originality as an exercise of freedom", the Court relies on functionality to exclude certain creations from copyright protection. This was particularly clear in $B S A$, where the Court fleshed out the merger doctrine: if the creation was dictated by functionality concerns, then the creation was not free and therefore it cannot be original. ${ }^{44}$

Although by now the kernel of the European concept of originality seems to be defined, knowing how demanding it is remains a source of

\footnotetext{
${ }^{40}$ Judgment of 1 December 2011, Eva-Maria Painer v. Standard Verlags Gmbh and Others, C-145/10, Painer, EU:C:2011:798, paragraphs 89 and 90.

${ }^{41}$ Judgment of 4 October 2011, Karen Murphy v. Media Protection Services Ltd., C-403/08 and C-429/08, EU:C:2011:631, paragraph 98.

${ }^{42}$ Even though this passage is primarily concerned with subject matter, the sentence in my view means that, for the Court, subject matter is defined by the possibility of originality. Only those fields of activity in which free creative choices can occur, thus generating original creations, are regarded as copyright subject matter. In my reading the Court does not divide subject matter from criteria of eligibility (originality), but makes the former dependant on the latter.

${ }^{43}$ Judgment of 2 May 2012, SAS Institute Inc. v. World Programming Ltd., C-406/10, EU:C:2012:259, paragraph 67.

${ }^{44}$ See Judgment of 22 December 2010, BSA v. Ministerstvo kultury, C-393/09, EU:C:2010:816, paragraph 49 .
} 
contention. In fact, by admitting that 11 words (in Infopaq) or a user manual (SAS Institute) might be protected by copyright, one could say that the $\mathrm{CJEU}$ is not too demanding in terms of originality. ${ }^{45}$

Lucas/Lucas ${ }^{46}$ believe that the French conception is only marginally affected and the Court has favoured a droit d'auteur approach. Andreas Rahmatian ${ }^{47}$ writes that it is likely that the CJEU increased the UK standard, but believes that the current standard is chameleonic and not a pure concession to the droit d'auteur conception, contrary to what some have claimed. Axel Nordemann ${ }^{48}$ submits that this case law leads to a decrease in the original German criterion. Most commentators seem to agree that this evolution means a departure from their national traditions towards a middle ground.

A different query is whether the Court provided any further guidance regarding copyright eligibility.

\section{Anything else about the concept of work?}

When addressing copyright eligibility the copyright and droit d'auteur, traditions differ not only in the threshold of originality required to grant copyright, but also concerning the demand (or lack thereof) of fixation (recording in material form) and the need of fitting the creation into one of a fixed set of categories.

According to UK law, a creation can only enjoy copyright if it is recorded in a material form (that is the fixation requirement) and, cumulatively, fits into one of eight categories: literary, dramatic, musical, or artistic works (s.1(1)(a) CDPA), sound recordings, films or broadcasts (s.1(1)(b) CDPA), and the typographical arrangement of published editions (s.1(1)(c)) This closed list system means that if a creation, albeit very creative and even innovative, does not correspond to one of such types it will be excluded from copyright protection. Courts in the UK have therefore refused to grant protection to the Stormtrooper helmet (of the Star Wars series) and an arrangement of objects, including a white Rolls Royce car inside an

\footnotetext{
${ }^{45}$ Thomas Margoni, “The harmonisation”, 95.

${ }^{46}$ André Lucas, Henri-Jacques Lucas, and Agnès Lucas-Schlötter, Traité de la Propriété Littéraire et Artistique (Paris: Lexis-Nexis, 2012), 135.

47 "Originality in UK copyright law: The old 'skill and labour' doctrine under pressure", International Review of Intellectual Property and Competition Law 44 (1) (2013): 15 and 18.

${ }^{48}$ In Wilhelm Nordemann and Friedrich Karl Fromm, Urheberrecht: Kommentar zum Urheberrechtsgesetz und zum Urheberrechtswahrnehmungsgesetz (Stuttgart: Kohlhammer, 2008), paragraph 2 UrhG rn 150.
} 
empty swimming pool (to be featured in a cover of an album by the British band Oasis) since these did not constitute sculptures. ${ }^{49}$

By suggesting in $B S A$ that Graphic User Interfaces could be protected by copyright, the CJEU called into question the compatibility of the closed list approach with EU law. ${ }^{50}$ On the other hand, until now the CJEU had not dealt with the fixation requirement. ${ }^{51}$ To some this has been addressed in the CJEU's most recent decision, one concerning a cheese.

\section{The cheese}

In the latest decades, the possibility of protecting smells and tastes by intellectual property has been debated and tested. Commentators often emphasise how Intellectual Property protection would mean an undue and disproportionate restriction on freedom, namely due to the functional or technical nature of perfumes and foodstuffs. ${ }^{52}$ Nevertheless, some courts have granted copyright protection to perfumes, ${ }^{53}$ which sparked a vigorous debate. ${ }^{54}$ The discussion has likewise been had regarding culinary creations. ${ }^{55}$

Recently the CJEU was asked to rule on the copyright eligibility of the taste of a cheese. A Dutch company, Levola, took the view that another company (Smilde) was infringing its copyright in the taste of its Heksenkaas cheese. In the context of this litigation the Regional Court of Appeal of Arnhem-Leeuwarden in the Netherlands asked a detailed set of questions

\footnotetext{
${ }^{49}$ Creation Records v. News Group Newspapers [1997] EWHC Ch 370 (Oasis) and Lucasfilm Limited v. Ainsworth [2011] UKSC 39 (Star Wars). On this issue and in greater detail see Justine Pila, "Copyright and its categories of original works", Oxford Journal of Legal Studies 30 (2010): 229-254. ${ }^{50}$ Leistner, "Copyright", 627; Rosati, Originality, 187 and Christian Heinze, "Software als Schutzgegenstand des Europäischen Urheberrechts", Journal of Intellectual Property, Information Technology and E-Commerce Law 2(1) (2011): 104.

${ }^{51}$ Tatiana-Eleni Synodinou, "The foundations of the concept of work in European copyright law", in Codification of European Copyright Law: Challenges and Perspectives, ed. Tatiana-Helene Synodinou (Alphen Aan Den Rijn: Wolters Kluwer, 2012), 111.

${ }^{52}$ Leon Calleja, "Why copyright law lacks taste and scents", Journal of Intellectual Property Law (2013): 31; Catherine Seville, “Copyright in perfumes: Smelling a rat", Cambridge Law Journal (2007): 51.

${ }^{53}$ See the decision of the Dutch Supreme Court (Lancôme v. Kecofa) of 16 June 2006 (NL:PHR:2006:AU8940). For more case law on the issue of perfumes see Justine Pila and Paul Torremans, European Intellectual Property Law (Oxford: Oxford University Press, 2016), 276.

${ }^{54}$ For a summary cf. Antoon Quaedvlieg, "Copyright and perfume: Nose, intellect and industry”, Revue Internationale du Droit d'Auteur 230 (2011) 20-34. In great detail see Stefan Fröhlich, Düfte als Geistiges Eigentum (Tübingen: Mohr Siebeck, 2008) and Claire Guillemin, Law et Odeur: Fragrance Protection in the Fields of Perfumery and Cosmetics (Baden-Baden: Nomos, 2016).

${ }^{55}$ See Christopher Buccafusco, "On the legal consequences of sauces: Should Thomas Keller's recipes be per se copyrightable?” Cardozo Arts \& Entertainment Law Journal (2007): 1121-1156.
} 
to the CJEU in order to determine if and how the taste of a cheese could benefit from copyright protection.

Advocate-General Wathelet issued an opinion suggesting a negative answer. However, his arguments were rather weak and the analysis was poor. First he stated that a work must be "identifiable with sufficient precision and objectivity" in order to enjoy protection, making an analogy with trade mark case law. ${ }^{56}$ This analogy is logically flawed since the cited requirement in trade mark law is explained by the existence of a registration and the need to make the sign perceptible to the public. These reasons do not apply in the field of copyright law. Following the identification argument, Wathelet stated.57 "tastes themselves are ephemeral, volatile and unstable militates, in my view, against their precise and objective identification and, therefore, their classification as works for the purposes of copyright". This seems to be incorrect as well. Otherwise, choreographies, performances, sand, chocolate, ice or paper sculptures, all of which lack permanence, would have to be excluded from copyright protection.

The Court's decision, on 13 November 2018, was not much better in terms of justification.

It began by stating that: ${ }^{58}$ "The directive makes no express reference to the laws of the Member States for the purpose of determining the meaning and scope of the concept of a 'work'. Accordingly, in view of the need for a uniform application of EU law and the principle of equality, that concept must normally be given an autonomous and uniform interpretation throughout the European Union". With this sentence the Court confirmed that it has the last word on defining the subject matter of copyright.

Confirming some fears of a "theoretical muddle", ${ }^{59}$ the Court stated: ${ }^{60}$ "two cumulative conditions must be satisfied for subject matter to be

${ }^{56}$ Opinion of Advocate General Wathelet delivered on 25 July 2018, Levola Hengelo BV v. Smilde Foods BV, Case C-310/17, EU:C:2018:618, paragraph 56.

${ }^{57}$ Opinion of Advocate General Wathelet delivered on 25 July 2018, Levola Hengelo BV v. Smilde Foods BV, Case C-310/17, EU:C:2018:618, paragraph 60.

${ }^{58}$ Judgment of 13 November 2018, Levola Hengelo BV v. Smilde Foods BV, Case C-310/17, EU:C:2018:899, paragraph 33.

${ }^{59}$ Andreas Rahmatian, "European copyright inside or outside the European Union: Pluralism of copyright laws and the "Herderian Paradox", International Review of Intellectual Property and Competition Law 47 (2016): 924: "If the CJEU is understood as not distinguishing between work and originality, but considers these two concepts as united in one as 'original work', this creates a theoretical muddle".

${ }^{60}$ Judgment of 13 November 2018, Levola Hengelo BV v. Smilde Foods BV, Case C-310/17, EU:C:2018:899, paragraph 35. 
classified as a 'work' within the meaning of Directive 2001/29." And explained: ${ }^{61}$ "First, the subject matter concerned must be original in the sense that it is the author's own intellectual creation (...) Secondly, only something which is the expression of the author's own intellectual creation may be classified as a 'work' within the meaning of Directive 2001/29".

These two conditions are intertwined and at first seem to lack autonomous meaning. It is hard to see the additional content of the second condition. If originality means the author's own intellectual creation (first condition) and a work must be an expression of the author's own intellectual creation (second condition), it would be easier to state one condition only: the work must be original. ${ }^{62}$

However, in paragraph 39 the Court of Justice relies on the word "expression" used in the second condition and the idea-expression dichotomy to break this logical deadlock. After having recalled that "copyright protection may be granted to expressions, but not to ideas, procedures, methods of operation or mathematical concepts as such", ${ }^{63}$ the Court concluded "Accordingly, for there to be a 'work' as referred to in Directive 2001/29, the subject matter protected by copyright must be expressed in a manner which makes it identifiable with sufficient precision and objectivity, even though that expression is not necessarily in permanent form". ${ }^{64}$ This is a good example of non sequitur. One cannot derive the need of identification from the idea-expression dichotomy. Even though the expression must manifest itself in the outside world, the need for a creation to be identifiable was never regarded as a requirement for copyright protection. ${ }^{65}$

\footnotetext{
${ }^{61}$ Judgment of 13 November 2018, Levola Hengelo BV v. Smilde Foods BV, Case C-310/17, EU:C:2018:899, paragraphs 36 and 37.

${ }^{62}$ Traditionally, originality is seen as one of several requirements for a creation to be regarded as copyright protected work. In that sense, one might have creations that are non-original or that for some other reason (e.g. lack of fixation or relevant connection with the territory of a State as well as the lapse of the copyright term) are not protected by copyright. According to the Court, are these to be called "works" nonetheless?

${ }^{63}$ Judgment of 13 November 2018, Levola Hengelo BV v. Smilde Foods BV, Case C-310/17, EU:C:2018:899, paragraph 39.

${ }^{64}$ Judgment of 13 November 2018, Levola Hengelo BV v. Smilde Foods BV, Case C-310/17, EU:C:2018:899, paragraph 40.

${ }^{65}$ Eleonora Rosati suggested this meant the introduction of a fixation requirement (https://ipkitten.blogspot.com/2018/11/the-levola-hengelo-cjeu-decision.html). However, I believe this is reading too much into the Court's words. That reading would run counter to previous opinions according to which CJEU's case law would force the UK to dispense with the fixation requirement (e.g. Johnathan Griffiths, "Dematerialization, pragmatism and the European copyright revolution", Oxford Journal of Legal Studies 33(4) (2013): 769-790).
} 
However, the Court justifies it with the needs of several people, namely "authorities responsible for ensuring that the exclusive rights inherent in copyright are protected must be able to identify, clearly and precisely, the subject matter so protected (...) individuals, in particular economic operators, who must be able to identify, clearly and precisely, what is the subject matter of protection which third parties, especially competitors, enjoy" ${ }^{66}$

Taking all this into account, and since "The taste of a food product cannot (...) be pinned down with precision and objectivity. Unlike, for example, a literary, pictorial, cinematographic or musical work, which is a precise and objective form of expression, the taste of a food product will be identified essentially on the basis of taste sensations and experiences, which are subjective and variable since they depend, inter alia, on factors particular to the person tasting the product concerned, such as age, food preferences and consumption habits, as well as on the environment or context in which the product is consumed", ${ }^{67}$ the Court rejected the possibility of copyright protection for taste.

Although to a certain extent the understanding and enjoyment of literary, pictorial, cinematographic or musical works is also dependent on subjective and variable experiences, it seems true that there is a difference in degree. Music will feel different to each listener but the sound will be the same; however, smell or taste will not only feel but objectively be different for each person.

Nonetheless, none of the advanced reasons seems convincing enough to explain the exclusion of taste from the realm of copyright.

What could the proper reasons be?

Some have suggested the real reason should be functionality and/or lack of artistic nature. In that vein, the French Cour de Cassation ${ }^{68}$ excluded the copyright of perfumes stressing that producing perfumes is more of an industrial activity than an artistic one. ${ }^{69}$ In fact, some authors, following the formulation of the Berne Convention, focus on subject matter eligibility and suggest that copyright can only be attributed to literary, artistic or

\footnotetext{
${ }^{66}$ Judgment of 13 November 2018, Levola Hengelo BV v. Smilde Foods BV, Case C-310/17, EU:C:2018:899, paragraph 41.

${ }^{67}$ Judgment of 13 November 2018, Levola Hengelo BV v. Smilde Foods BV, Case C-310/17, EU:C:2018:899, paragraph 42.

${ }^{68}$ Judgment of 10 December 2013 (FR:CCASS:2013:CO01205), mentioned in Judgment of 13 November 2018, Levola Hengelo BV v. Smilde Foods BV, Case C-310/17, EU:C:2018:899, paragraph 24 ${ }^{69}$ It also highlighted it is not an expression and that the individual perception of a perfume is much differentiated. The last two arguments can be found in the Levola Hengelo decision.
} 
scientific creations. ${ }^{70}$ The Court itself stated: ${ }^{71}$ "Under Article 2(1) of the Berne Convention, literary and artistic works include every production in the literary, scientific and artistic domain, whatever the mode or form of its expression may be". If this can be read as a death knell for the closed list/ categorisation approach, ${ }^{72}$ it is no less true that one can derive from here the idea that perfumes are excluded from protection precisely because they lack artistic nature.

If that is the case, then it becomes clear that the Court of Justice is now also considering subject matter and there has not been a total exclusion of any other criteria but originality in order to determine copyright eligibility. ${ }^{73}$ At the same time, a whole universe of other questions spring to mind: how are we to assess artistic nature? Is there some intrinsic quality that turns an object into art or is it a matter of general (and if so, how general) perception? Should we rely on the perception of experts, the general public, a specialised public? Which public then? Can there be regional variations (say an object is considered art in a Member-State but not in another)? When is the artistic nature to be assessed? Can one object "become" art throughout its existence? Or, conversely, lose its artistic nature?

I submit that the Court did not want to open the door to all these inquiries and therefore chose to give a cryptic and short answer to the question. Its aim was clear - rejecting the possibility to protect taste by copyright -, its reasoning was purposely obscure. However, it might be forced to explain itself better due to a pair of jeans.

\section{The jeans}

The extent to which copyright can co-exist with designs is the subject of a long-time controversy. The existing approaches are usually divided in three. $^{74}$

\footnotetext{
${ }^{70}$ In Portugal see e.g. Pedro Sousa e Silva, A Protecção Jurídica do Design (Coimbra: Almedina, 2017), 174-188, in Germany e.g. Eugen Ulmer, Urheber- und Verlagsrecht (Berlin: Springer, 1980), 150.

${ }^{71}$ C-310/17, Levola Hengelo, EU:C:2018:899, paragraph 39.

${ }^{72}$ That being the opinion of Eleonora Rosati (see https://ipkitten.blogspot.com/2018/11/the-levolahengelo-cjeu-decision.html).

${ }^{73}$ For further analysis see Stef van Gompel and Erlend Lavik, "Quality, merit, aesthetics and purpose: An inquiry into EU copyright law's eschewal of other criteria than originality", Revue Internationale du Droit d'Auteur 236 (2013): 100-295, concluding that this exclusion of additional criteria should not be regarded as too strict or taken too seriously.

${ }^{74}$ In this section I follow Nuno Sousa e Silva, The Ownership Problems of Overlaps in European Intellectual Property (Baden-Baden: Nomos, 2014), 50-54.
} 
One, called no cumulation, relies on a requirement of separability, according to which only the separate ornamental elements can be protected by copyright but not a piece that is simultaneously aesthetic and functional. This was the old Italian approach of scindibilitá ${ }^{75}$ and is the current position in the US. ${ }^{76}$

The second approach, of partial cumulation, relies on additional "filtering requirements" such as a higher threshold of originality and/or artistic quality, registration or a maximum number of reproductions to select which designs are to be protected under copyright. ${ }^{77}$ This is found in Germany and also in recent decisions of Portuguese and Spanish courts. ${ }^{78}$

The third orientation is full (or perfect) cumulation. Grounded on a certain understanding of the theory of the unity of the art (attributed to Eugéne Pouillet) it makes no distinction between general creations and works of applied arts. This is found in Belgium, the Netherlands, and France.

Article 17 of the Design Directive (similar to Article 96/2 of Council Regulation (EC) No. 6/2002 of 12 December 2001 on Community designs) states that "A design protected by a design right registered in or in respect of a Member State in accordance with this Directive shall also be eligible for protection under the law of copyright of that State as from the date on which the design was created or fixed in any form. The extent to which,

\footnotetext{
${ }^{75}$ According to Article 2 number 4 of the previous law, copyright could only be granted to the works of applied art if their artistic merit could be detached from the industrial nature of the product to which it was applied. In 2001 (with Decreto Legislativo 2 febbraio 2001, n. 95 Attuazione della direttiva 98/71/CE relativa alla protezione giuridica dei disegni e dei modelli) the Italian legislator, transposing the Design Directive, amended its copyright law, adding a new number 10 to Article 2 of its Copyright Act, according to which "the works of industrial design that are creative and have artistic value" are now protected by copyright. See Philipp Fabbio, Disegni e Modelli (Padova: CEDAM, 2012), 185-194.

${ }_{76} 17$ USC $\$ 101$ (definition of "pictorial, graphic and sculptural work").

${ }^{77}$ Analysing some of the criteria see Yves Gaubiac, "La théorie de l'unité de l'art", Revue Internationale du Droit d'Auteur 111 (1982): $43 \mathrm{ff}$.

${ }^{78}$ E.g., in Portugal, case 1607/10.3TBBRG.G1, decision by Guimarães Court of Appeal of 27 February 2012 (see Nuno Sousa e Silva, "No copyright protection for tap designs - says Portuguese Court”, Journal of Intellectual Property Law \& Practice (2013): 686-687) and in Spain decision 561/2012 (official publication number STS 6196/2012), by the Civil Section of The Spanish Supreme Court, 27 September 2012 (see Nuno Sousa e Silva, "Novelty is not enough: Spanish Supreme Court rejects unity of the art in an enigmatic decision", Journal of Intellectual Property Law \& Practice (2013): 825-826).
} 
and the conditions under which, such a protection is conferred, including the level of originality required, shall be determined by each Member State".

It was believed that this provision barred the no cumulation approach but allowed Member-States to choose between a partial and a full cumulation system. ${ }^{79}$ However, as explained above (5.), the CJEU decision in Flos raised doubts in this respect. ${ }^{80}$

In the context of the litigation between G-Star (a Dutch company) and Cofemel (a Portuguese textile company trading under the trade mark "Tiffosi") regarding the imitation by the latter of jeans and sweaters, the question arose as to whether these fashion designs were eligible for copyright protection. Up until recently Portuguese courts had favoured a partial cumulation approach, ${ }^{81}$ and so the first instance rejected the possibility of copyright protection on the grounds that these creations lacked artistic character. However, the second instance, citing Infopaq, reversed the decision and considered that copyright would apply. ${ }^{82}$ According to the Appeals Court, no other criterion except for "normal" originality should determine if a pair of jeans can be protected by copyright. The losing party appealed to the Supreme Court, which issued a preliminary ruling request with the following questions: ${ }^{83}$ "1) Does the interpretation by the Court of Justice of the European Union of Article 2(a) of Directive 2001/29/EC 1 preclude national legislation - in the present case, the provision in Article 2(1)(i) of the Código de Direitos de Autor e Direitos Conexos (CDADC) - which confers copyright protection on works of applied art, industrial designs and works of design which, in addition to the utilitarian purpose they serve, create their own visual and distinctive effect from an aesthetic point of view, their originality being the fundamental criterion which governs the grant of protection in the area of copyright? 2) Does the interpretation by the Court of Justice of the European Union of Article 2(a) of Directive 2001/29/EC preclude national legislation - in the present case,

\footnotetext{
${ }^{79}$ Sam Ricketson and Uma Suthersanen, “The design/copyright overlap: Is there a resolution?", in Overlapping Intellectual Property Rights, Neil J. Wilkof and Shamnad Basheer (eds.) (New Delhi, India: Oxford University Press, 2013), 176. This has also been the expressed in opinion of Advocate General Sánchez-Bordona delivered on 31 May 2016 in case C-169/15, Montis Design, EU:C:2016:383, paragraphs 47 and 60

${ }^{80}$ See also Thomas Margoni, "The harmonisation", 97-101.

${ }^{81}$ Discussing that question in depth see Pedro Sousa e Silva, A Protecção Jurídica, 154-289.

${ }^{82}$ Procedure no. 268/13.2YHLSB.L1-7, decision of the Lisbon Court of Appeals of 21 February 2017.

${ }^{83}$ C-683/17, Cofemel, application published on 26 January 2018.
} 
the provision in Article 2(1)(i) of the CDADC - which confers copyright protection on works of applied art, industrial designs and works of design if, in the light of a particularly rigorous assessment of their artistic character, and taking account the dominant views in cultural and institutional circles, they qualify as an 'artistic creation' or 'work of art'?".

These questions will force the Court to establish if the same criteria to define the notion of work in general also apply in the field of designs and the applied arts. In other words, how relevant was the obiter dicta in Flos and who is right, the German or the Dutch Supreme Court (see supra 5.)? Taking into account the pro-harmonisation agenda of the CJEU, ${ }^{84} \mathrm{I}$ believe the Court will consider that Infopaq is also applicable to designs, and that Member-States are not free to establish additional criteria of eligibility. ${ }^{85}$

Withal, I believe the most interesting question is the second one. Unfortunately, I foresee that the Court might very well excuse itself from answering it. I submit that it is likely that the reasoning will be as follows: Infopaq also applies to designs, thus no additional criteria can be applied. Therefore, there is no need to reply to the second question. However, should that be the case, at least the meaning of Levola Hengelo will be clarified. ${ }^{86}$ The Court might flesh out if subject matter considerations are relevant for the EU notion of work. We might get a hint of the Court's likely understanding once the decision concerning a military report is out.

\section{The military report}

In C-469/17, Funke Medien, known as the "Afghanistan Papers" case, the CJEU's intervention was requested in the course of litigation between the German Government and a press publisher. The former refused access of the latter to weekly military reports concerning German military activities in Afghanistan between 2001 and 2012 invoking security-sensitive interests of the federal armed forces. However, the news organisation got hold of those reports and published a part of them in the website of its newspaper Westdeutsche Allgemeine Zeitung. Following this publication, the German Government brought an action against Funke Medien for

\footnotetext{
${ }^{84}$ Highlighted by Estelle Derclaye “The Court of Justice copyright case law: Quo vadis?”, European Intellectual Property Review 36 (2014): 716-723.

${ }^{85}$ Along these lines see Rosati, Originality, 123. Even if that means a total disregard for the principle of conferral.

${ }^{86}$ In that the exclusion of taste is not due to the lack of artistic nature of culinary creations.
} 
copyright infringement, alleging a violation of the reproduction and communication to public rights.

It was in this context that the Bundesgerichtshof decided to refer three questions to the CJEU for a preliminary ruling. These deal with (1) the latitude in terms of implementation in national law given by Directive $2001 / 29$, (2) the way in which fundamental rights are to be taken into account when ascertaining the scope of the exceptions or limitations, and (3) the possibility of deriving exceptions from the fundamental rights of freedom of information or freedom of the media beyond the ones provided for in the said Directive.

None of the questions deal with copyright eligibility. Notwithstanding, Advocate-General Szpunar believes that the case should be solved from that perspective. ${ }^{87}$ According to his opinion: $: 88$ "It seems to me to be rather unlikely that the author or authors of those documents, whose identity is unknown but who are probably civil servants or officers of the federal armed forces, were able to make free and creative choices in order to express their creative abilities when drafting those documents. The content of purely informative documents that are inevitably drafted in simple and neutral terms is entirely determined by the information they contain, so that such information and its expression become indissociable, thus precluding all originality. A degree of effort and skill is required to draw them up, but those elements on their own cannot justify copyright protection. During the discussions in that regard at the hearing, the parties also argued that the structure of the documents at issue could itself be protected by copyright. However, that structure consists in setting out evenly spaced information concerning each foreign mission in which the federal armed forces are participating. Therefore, I do not think that the structure of those reports is more creative than their content".

It is hard to predict whether the Court will follow the AdvocateGeneral's suggestion. If it does, I believe it will stick to originality and the idea-expression dichotomy and not delve into the particular nature of the documents and its literary or artistic nature (or lack thereof). But, as usual, the unexpected can happen.

\footnotetext{
${ }^{87}$ Opinion of Advocate General Szpunar, delivered on 25 October 2018, Funke Medien, Case C-469/17, EU:C:2018:870.

${ }^{88}$ Opinion of Advocate General Szpunar, delivered on 25 October 2018, Funke Medien, Case C-469/17, EU:C:2018:870, paragraph 19.
} 


\section{Conclusion}

As I have tried to show, it seems clear that the CJEU has adopted a horizontal harmonised notion of work. Work is now undoubtedly regarded as an autonomous concept of EU law. However, its meaning remains highly undetermined and therefore contentious. It is not only undetermined by lack of case law, which is in earnest development (even if not always with clarity), but also inherently undetermined. ${ }^{89}$ In this last sense, it could be said that to a certain extent the notion of work is rebel to harmonisation. Should the Court choose to give relevance to subject matter considerations, national and personal differences concerning what can be deemed artistic (and even how to make that determination) will perpetuate the uncertainty. Every time a decision in this field is issued, different interpretations arise and are thoroughly debated.${ }^{90}$ It is only natural that national courts will (as already have) frequently diverge. While the CJEU has been expanding and defining the borders of the notion of work, it might also be discovering and mapping the boundaries of harmonisation. That is why I believe that we will keep having abundant but unclear case law in this field for several years to come. ${ }^{91}$

\section{Bibliography}

Aplin, Tanya. "Subject matter". In Research Handbook on the Future of EU Copyright, edited by Estelle Derclaye, 49-76. Cheltenham: Edward Elgar, 2009.

Bently, Lionel, Brad Sherman, Dev Gangjee, and Phillip Johnson. Intellectual Property Law. Oxford: Oxford University Press, 2018.

Bently, Lionel. “The return of industrial copyright?". European Intellectual Property Review 34, (2012): 654-672.

\footnotetext{
${ }^{89}$ The same can be said of originality. As stated by Rahmatian, "Originality" 22: "A proper definition of the originality criterion of 'own intellectual creation' has not yet been given, only approximations to this term have been attempted so far. In fact, this expression can be filled with the intellectual background of the legal culture in which it is applied (...) Such a malleable concept is particularly susceptible to being aligned to and incorporated into the legal tradition and mentality of each distinctive European jurisdiction - rather contrary to the intention of harmonisation". Along the same lines see Thomas Margoni, "The harmonisation", 101.

${ }^{90}$ For an overview of the debates see Mireille van Eechoud, "Along the road to uniformity - Diverse readings of the Court of Justice judgments on copyright work", Journal of Intellectual Property, Information Technology and E-Commerce Law 3(1) (2012): 60-80.

${ }^{91}$ In a more optimistic vein, speaking of a "mutual persuasion", see Leistner, "Copyright", 630.
} 
Buccafusco, Christopher. "On the legal consequences of sauces: Should Thomas Keller's recipes be per se copyrightable?". Cardozo Arts \& Entertainment Law Journal (2007): 1121-1156.

Calleja, Leon. "Why copyright law lacks taste and scents". Journal of Intelelctual Property Law (2013): 1-31.

Casas Vallés, Ramón. "The requirement of originality”. In Research Handbook on the Future of EU Copyright, edited by Estelle Derclaye, 102-132. Cheltenham: Edward Elgar, 2009.

Derclaye, Estelle. “Infopaq International A/S v. Danske Dagblades Forening (C-5/08): wonderful or worrisome? The impact of the ECJ ruling in Infopaq on UK copyright law". European Intellectual Property Review 32 (2010): 247-251.

Derclaye, Estelle. "The copyright/design interface in Italy". In The Copyright/Design Interface: Past, Present and Future, edited by Estelle Derclaye, 269-296. Cambridge: Cambridge University Press, 2018.

Derclaye, Estelle. “The Court of Justice copyright case law: Quo vadis?”. European Intellectual Property Review 36 (2014): 716-723.

Fabbio, Philipp. Disegni e Modelli. Padova: CEDAM, 2012.

Favale, Marcella, Martin Kretschmer and Paul C. Torremans. "Is there a EU copyright jurisprudence? - An empirical analysis of the workings of the European Court of Justice”. The Modern Law Review (2016): 31-75.

Fröhlich, Stefan. Düfte als Geistiges Eigentum. Tübingen: Mohr Siebeck, 2008.

Gaubiac, Yves. "La théorie de l'unité de l'art". Revue Internationale du Droit d'Auteur 111 (1982): 3-71.

Gendreau, Ysolde (ed.). Copyright and Photographs: An International Survey. London: Kluwer Law International, 1999.

Gervais, Daniel. "Feist goes global: A comparative analysis of the notion of originality in copyright law". Journal of the Copyright Society of the U.S.A. 49 (2002): 949-981.

Griffiths, Johnathan. "Dematerialization, pragmatism and the European copyright revolution". Oxford Journal of Legal Studies 33(4) (2013): 769-790.

Guillemin, Claire. Law et Odeur: Fragrance Protection in the Fields of Perfumery and Cosmetics. Baden-Baden: Nomos, 2016.

Heinze, Christian. "Software als Schutzgegenstand des Europäischen Urheberrechts". Journal of Intellectual Property, Information Technology and E-Commerce Law 2(1) (2011): 97-113.

Jehoram, Herman Cohen. "Cumulation of protection in the EC design proposals". European Intellectual Property Review 16 (1994): 514-520.

Jotzo, Florian. "Der EuGH als Interimsnormgeber im digitalen Urheberrecht”. Zeitschrift für Geistiges Eigentum 9(4) (2017): 447-470. 
Leistner, Matthias. "Copyright at the interface between EU law and national law: Definition of 'work' and 'right of communication to the public"'. Journal of Intellectual Property Law \& Practice (2015): 626-637.

Lucas, André, Henri-Jacques Lucas, and Agnès Lucas-Schlötter. Traité de la Propriété Littéraire et Artistique (Paris: Lexis-Nexis, 2012)

Margoni, Thomas. "The harmonisation of EU copyright law: The originality standard". In Global Governance of Intellectual Property in the 21st Century: Reflecting Policy through Change, edited by Mark Perry, Mark, 85-105. Cham: Springer, 2016.

Nordemann, Wilhelm, and Friedrich Karl Fromm. Urheberrecht: Kommentar zum Urheberrechtsgesetz und zum Urheberrechtswahrnehmungsgesetz. Stuttgart: Kohlhammer, 2008.

Ohly, Ansgar. "The case for partial cumulation in Germany". In The Copyright/Design Interface: Past, Present and Future, edited by Estelle Derclaye, 128-170. Cambridge: Cambridge University Press, 2018.

Pila, Justine. "Copyright and its categories of original works". Oxford Journal of Legal Studies 30 (2010): 229-254.

Pila, Justine, and Paul Torremans. European Intellectual Property Law. Oxford: Oxford University Press, 2016.

Quaedvlieg, Antoon. "Copyright and perfume: Nose, intellect and industry". Revue Internationale du Droit d'Auteur 230 (2011): 7-77.

Quaedvlieg, Antoon. "The copyright/design interface in the Netherlands". In The Copyright/Design Interface: Past, Present and Future, edited by Estelle Derclaye, 36-79. Cambridge: Cambridge University Press, 2018.

Rahmatian, Andreas. "European copyright inside or outside the European Union: Pluralism of copyright laws and the 'Herderian Paradox"'. International Review of Intellectual Property and Competition Law 47 (2016): 912-940.

Rahmatian, Andreas. "Originality in UK copyright law: The old 'skill and labour' doctrine under pressure". International Review of Intellectual Property and Competition Law 44 (2013): 4-34.

Ricketson, Sam and Uma Suthersanen. "The design/ copyright overlap: Is there a resolution?". In Overlapping Intellectual Property Rights, edited by Neil J. Wilkof and Shamnad Basheer, 159-187. New Delhi, India: Oxford University Press, 2013.

Rosati, Eleonora. Originality in EU Copyright: Full Harmonization through Case Law. Cheltenham, UK: Edward Elgar, 2013.

Schulze, Gernot. "Schleichende Harmonisierung des urheberrechtlichen Werkbegriffs? - Anmerkung zu EuGH Infopaq/DDF”. Gewerblicher Rechtsschutz und Urheberrecht (2009): 1019-102. 
Seville, Catherine. "Copyright in perfumes: Smelling a rat". Cambridge Law Journal (2007): 49-52.

Sousa e Silva, Nuno. "No copyright protection for tap designs - says Portuguese Court". Journal of Intellectual Property Law \& Practice (2013): 686-687.

Sousa e Silva, Nuno. "Novelty is not enough: Spanish Supreme Court rejects unity of the art in an enigmatic decision". Journal of Intellectual Property Law \& Practice (2013): 825-826.

Sousa e Silva, Nuno. The Ownership Problems of Overlaps in European Intellectual Property. Baden-Baden: Nomos, 2014.

Sousa e Silva, Pedro. A Protecção Jurídica do Design. Coimbra: Almedina 2017.

Strowel, Alain. Droit d'Auteur et Copyright, Divergences et Convergences: Étude de Droit Comparé. Bruxelles: E. Bruylant, 1994.

Ulmer, Eugen. Urheber- und Verlagsrecht. Berlin: Springer, 1980.

Van Eechoud, Mireille. "Along the road to uniformity - Diverse readings of the Court of Justice judgments on copyright work". Journal of Intellectual Property, Information Technology and E-Commerce Law 3(1) (2012): 60-80.

Van Gompel, Stef and Erlend Lavik. "Quality, merit, aesthetics and purpose: An inquiry into EU copyright law's eschewal of other criteria than originality". Revue Internationale du Droit d'Auteur 236 (2013): 100-295. 